\title{
ANALISIS KESIAPAN UMKM BATIK DI KOTA MADIUN DALAM PENERAPAN SAK EMKM
}

\author{
Diza Satrina Luchindawati, Elva Nuraina, Elly Astuti* \\ Program Studi Akuntansi, Universitas PGRI Madiun \\ *email : ellyastuti@unipma.ac.id* \\ DiPublikasi: 01/01/2020 \\ http://dx.doi.org/10.22225/kr.11.2.1154.190-196
}

\begin{abstract}
MSMEs are small-scale business activities that can be controlled by groups or groups of people who aim to make a profit. UMKM is one of the pillars of a country's economy. However, the development of MSMEs from year to year is less significant. That condition happens because of a lack of knowledge about business financial management. The office in charge of MSMEs in several regions has begun to aggressively introduce financial reports preparation as information for the decision-making process. This socialization generally uses the Financial Accounting Standards for Micro, Small, and Medium Enterprises (SAK EMKM) as the legal basis for preparing their financial statements. This study aims to determine the readiness of batik micro, small and medium enterprises (MSMEs) in Madiun City to apply SAK EMKM to their business financial reports. This research uses descriptive qualitative method. This study indicates that batik UMKM players in Madiun City are not ready to implement SAK EMKM.

Keywords: Readiness, Micro Small and Medium Enterprises (MSMEs), Financial Accounting Standards for Micro, Small and Medium Entities (SAK EMKM)

Abstrak

UMKM merupakan kegiatan usaha yang memiliki skala kecil yang bisa dikendalikan oleh kelompok maupun kumpulan orang yang memiliki tujuan untuk mendapatkan keuntungan. UMKM merupakan salah satu penyangga perekonomian sebuah negara. Namun demikian perkembangan UMKM dari tahun ke tahun kurang signifikan. Hal ini terjadi karena kurangnya pengetahuan mengenai pegelolaan keuangan usahanya. Dinas yang membawahi UMKM pada beberapa daerah mulai gencar memperkenalkan penyusunan laporan keuangan sebagai informasi untuk proses pengambilan keputusan. Sosialisasi tersebut pada umumnya menggunakan Standar Akuntansi Keuangan Entitas Mikro Kecil dan Menengah (SAK EMKM) sebagai dasar hukum penyusunan laporan keuangannya. Penelitian ini memiliki tujuan untuk mengetahui kesiapan dari pelaku Usaha Mikro Kecil dan Menengah (UMKM) batik di Kota Madiun dalam menerapkan SAK EMKM pada laporan keuangan usahanya. Penelitian ini menggunakan metode kualitatif deskriptif. Hasil penelitian ini menunjukkan pelaku UMKM batik di Kota Madiun belum siap menerapkan SAK EMKM.

Kata Kunci: Kesiapan, Usaha Mikro Kecil dan Menengah (UMKM), Standar Akuntansi Keuangan Entitas Mikro Kecil dan Menengah (SAK EMKM)
\end{abstract}

\section{PENDAHULUAN}

Usaha Mikro Kecil dan Menengah (Selanjutnya UMKM) adalah usaha ekonomi yang aktif serta bebas, dan dikelola oleh badan usaha yang bukan cabang perusahaan yang dikendalikan atau menjadi bagian secara langsung maupun tidak dengan usaha kecil atau besar (Undang Undang No. 20, 2008). UMKM juga merupakan aktivitas usaha yang memiliki skala kecil yang bisa dikendalikan oleh kelompok maupun kumpulan orang yang memiliki tujuan untuk mendapatkan keuntungan. Tetapi UMKM dalam pengelolaan usaha dan penerapan manajemen menjadi kurang profesional, hal ini berhubungan dengan penvusunan laporan keuangan
Semakin berkembangnya UMKM, Pemerintah Indonesia memberikan kemudahan bagi UMKM dalam mendapatkan tambahan modal dengan pengajuan kredit secara mudah. Laporan keuangan menjadi syarat bagi UMKM untuk mengajukan kredit. Laporan keuangan sebagai bahan analisis untuk menilai kemampuan dari UMKM dalam pelunasan kredit guna meminimalisir risiko gagal bayar.

Laporan keuangan juga digunakan untuk melakukan analisis untuk membuat keputusan finansial dan mempertanggungjawabkan manajemen pada penggunaan sumber daya di dalam usahanya. Tetapi nyatanya penyusunan 
laporan keuangan tidak mudah untuk sebagian pelaku UMKM. Permasalahan ini diakibatkan karena kurangnya pengetahuan tentang cara penyusunan laporan keuangan yang benar karena beberapa pelaku UMKM belum bisa melakukan pemisahan dana pribadi dengan keuangan usahanya. Apabila UMKM dipaksa dalam penyusunan laporan keuangan maka bisa saja laporan keuangan yang sudah dibuat tidak bisa dipercaya serta digunakan dalam pengambilan keputusan.

Pemerintah Indonesia saat ini sudah merencanakan untuk mewajibkan UMKM dalam melakukan penyusunan laporan keuangan. Dewan Standar Akuntansi Keuangan Ikatan Akuntan Indonesia (DSAK IAI) sudah melakukan pengesahan Standar Akuntansi Keuangan Entitas Mikro, Kecil, dan Menengah (selanjutnya SAK EMKM) pada tanggal 1 Januari 2018. SAK EMKM sebagai dasar dalam penyusunan laporan keuangan. Tetapi, sosialisai terkait SAK EMKM dirasakan kurang menyeluruh, karena banyak pelaku UMKM yang belum menerapkannya.

Sholikin \& Setiawan (2018) menyatakan bahwa terdapat kendala yang berdampak pada ketidaksiapan UMKM dalam melakukan implementasi SAK EMKM. Kendala tersebut

\section{TINJAUAN PUSTAKA}

\section{Kesiapan}

Menurut Kasus et al (2019) kesiapan adalah pernyataan kesiapan atau siap dari seseorang, organisasi atau bahkan sistem dalam pemenuhan sebuah aktifitas yang telah direncanakan. Kesiapan juga diartikan kemampuan seseorang dalam melakukan suatu hal dengan kondisi tertentu. Kesiapan pada penelitian ini adalah kondisi seseorang yang sudah siap dalam penerapan SAK EMKM di dalam usahanya dan dilihat dari aspek keadaan atau kondisi, kebutuhan, serta wawasan tentang SAK EMKM. Apabila pelaku UMKM sudah memenuhi aspek-aspek diatas, UMKM tersebut bisa dinilai telah siap dalam penerapan SAK EMKM di dalam laporan keuanganya.

\section{Usaha Mikro Kecil dan Menengah (UMKM)}

Peranan dari ekonomi kreatif yang makin meningkat untuk perekonomian di suatu wilayah, terutama pada pengembangan ekonomi yang berbasis Usaha Mikro Kecil dan Menengah (UMKM). Tidak heran apabila semakin banyak kota yang membuat ekonomi kreatif sebagai katalisator bagi nengembangan ekonomi di adalah pelaku UMKM tidak memiliki kesadaran terhadap pentingnya laporan keuangan dan kurangnya penyuluhan serta latihan yang berkaitan dengan SAK EMKM. Sulisti (2019) menunjukkan bahwa Pelaku UMKM sudah memahami dasardasar akuntansi namun belum mengetahui tentang SAK EMKM. Pelaku UMKM cukup siap melakukan pencatatan laporan keuangan yang berpedoman dengan SAK EMKM.

Berdasarkan data di Dinas Penanaman Modal Pelayanan Terpadu Satu Pintu Koperasi Usaha Mikro (DPMPTSPKUM) Kota Madiun terdapat 20.941 jenis usaha mikro, 2.196 jenis usaha kecil, dan 223 jenis usaha menengah. Salah satu sektor UMKM yang memiliki potensi cukup besar di Kota Madiun adalah sentra batik. Usaha batik di Kota Madiun relatif cukup dibandingkan dengan usaha makanan. Perkembangan UMKM cukup baik dan sudah banyak yang melakukan pencatatan laporan keuangan usahanya. Namun demikian penyusunan laporan keuangan masih dilakukan secara sederhana. Untuk itu, penelitian ini ditujukan untuk mengungkapkan kesiapan pelaku UMKM batik dalam penerapan SAK EMKM sesuai dengan wacana Pemerintah Indonesia yang mewajibkan UMKM melakukan penyusunan laporan keuangan.

daerahnya (Huda, 2017:77).

Savitri (2018) menyatakan bahwa bentuk dari UMKM bisa berupa persekutuan ataupun perusahaan perseorangan. Tujuan UMKM adalah untuk mengembangkan dan menumbuhkan usahanya dalam memajukan ekonomi negara menurut demokrasi ekonomi yang adil (Sulistyowati, 2017).

\section{Kriteria UMKM}

Sulisti (2019) mengatakan ciri UMKM adalah keadaan nyata yang lekat dengan kegiatan usaha atau tingkah laku pelaku usaha yang bersangkutan pada saat menjalankan usahanya. Ciri tersebut adalah ciri khas pelaku usaha yang sesuai dengan ukuran usahanya (Rafiqa, 2018). Sulisti (2019), mengelompokkan UMKM berdasarkan pandangan usahanya menjadi empat klasifikasi yaitu:

1. UMKM sektor informal, misalnya PKL (Pedagang Kaki Lima).

2. UMKM Mikro merupakan pelaku UMKM yang memiliki keahlian kreatif dan memiliki sifat pengrajin tetapi kurang dalam memiliki 
jiwa berwirausaha dalam mengembangkan usahanya.

3. Usaha Kecil Dinamis merupakan sekelompok pelaku UMKM yang dapat menjadi usahawan serta menerima kerja kontrak atau menjalin sebuah kerjasama dan melakukan ekspor.

4. UMKM yang mempunyai semangat berwirausaha yang siap dan cakap berubah untuk menjadi usaha yang besar dan berkembang (Fast Moving Enterprises)

\section{Peranan UMKM}

UMKM mempunyai peranan dengan pengaruh yang sangat besar bagi pendapatan negara. Salmiah et al (2015) mengatakan UMKM di bidang pertanian dan kerajinan menjadi sumber devisa bagi negara atau menjadi investasi untuk negara. Selain memiliki manfaat untuk pertumbuhan ekonomi, UMKM juga banyak ikut dalam mengurangi pengangguran di Indonesia (Salmiah et al, 2015). Hal ini dibuktikan dengan banyaknya kebutuhan tenaga kerja yang mengutamakan masyarakat sekitar. Dengan demikian, UMKM mampu meningkatkan kesejahteraan masyarakat.

\section{Permasalahan dalam UMKM}

Salmiah et al (2015) menjelaskan permasalahan yang biasa dihadapi oleh UMKM adalah:

a. Faktor Internal

Pertama, kekurangan modal. Salah satu alternatif penyelesaian masalah permodalan adalah penyusunan laporan keuangan. Ketika UMKM mampu menyusun laporan keuangan berdasarkan SAK EMKM, akses permodalan mereka akan semakin terbuka. UMKM dapat memperoleh permodalan dari bank ataupun lembaga finansial lainnya. Kedua, Sumber Daya Manusia (SDM) terbatas. Keterbatasan yang dimaksudkan adalah pendidikan yang formal yang relatif rendah, kurangnya wawasan serta keterampilan dalam pengelolaan usaha, sehingga mengakibatkan usahanya sulit berkembang.

b. Faktor Eksternal

Pertama, iklim usaha yang belum kondusif secara penuh pada kebijakan yang dibuat Pemerintah Indonesia dalam hal menumbuhkan dan mengembangkan UMKM. Ditinjau dari segi persaingan yang tidak adil antara pengusaha kecil dan besar. Kedua, infrastruktur yang terbatas, dikarenakan kemajuan IPTEK terhambat sehingga sarana dan prasarana yang dimiliki tidak berkembang cepat.

Rofiaty (2012:66) mengungkapkan kendala lain dari UMKM adalah tidak adanya peran aktif dari UMKM di Jawa Timur dalam memasarkan produknya melalui internet, padahal internet dinilai sangat efisien dan efektif dalam penjualan produk.

Menurut Arliani et al (2019) pemerintah memberikan perhatian yang besar untuk UMKM merupakan langkah yang strategis dan tepat serta yang dibutuhkan oleh masyarakat Indonesia. Bentuk perhatian Pemerintah untuk UMKM adalah membentuk Kementerian Negara Koperasi dan Usaha Kecil Menengah.

\section{Standar Akuntansi Keuangan Entitas Mikro Kecil Menengah (SAK EMKM)}

Standar Akuntansi Keuangan Entitas Mikro, Kecil, Menengah (SAK EMKM) sudah disahkan tahun 2016 berlaku untuk entitas yang tidak memiliki tanggung jawab kepada publik. Sama halnya dengan SAK ETAP (Standar Akuntansi Keuangan Entitas Tanpa Akuntabilitas Publik) yang sudah memenuhi kriteria usaha mikro, kecil, dan menengah yang telah diatur di dalam undangundang yang berlaku di Indonesia.

Setiady (2012) mengatakan entitas yang tanpa akuntabilitas merupakan perusahaan yang tidak mempunyai tanggung jawab kepada masyarakat luas yang tinggi serta menyediakan laporan demi tujuan umum untuk pelaku usaha yang tidak ada keterlibatan dalam usaha atau pengguna luar (eksternal).

Sedangkan perusahaan yang memiliki tanggung jawab kepada publik yang signifikan apabila perusahaan sudah membuat pengajuan pendaftaran, atau sedang membuat pendaftaran, pada pihak pasar modal dengan tujuan untuk penyediaan efek di dalam pasar modal atau perusahaan telah mengontrol aset dengan jumlah sebagai hak pelimpahan kepemilikan (fidusia) demi kelompok besar di masyarakat, contohnya bank, perusahaan asuransi, atau pedagang efek, reksa dana serta bank untuk investasi. SAK EMKM bisa dipakai oleh perusahaan yang tidak atau kriteria yang belum terpenuhi dan definisi di atas.

\section{METODE PENELITIAN}

Penelitian ini adalah penelitian kualitatif di Kota Madiun yang meliputi Galeri Batik Murni deskrintif Penelitian dilakukan di 3 UMKM Batik (Ialan_Halmahera) Batik Tulis Kenonon Madiun 
(Winongo), Batik Arum Melati (Jalan Pulanggeni, Josenan). Teknik pengumpulan data melalui wawancara dan dokumentasi. Teknik analisis data kualitatif mencakup hasil observasi, wawancara, menggunakan reduksi data, penyajian data

\section{HASIL DAN PEMBAHASAN}

Perkembangan standar SAK EMKM pada realisasinya yang belum dapat diterapkan dengan baik. Hal ini dikarenakan minimnya pengetahuan terkait dengan laporan keuangan dan banyaknya masyarakat yang tidak menerapkan dengan baik pencatatan laporan keuangan dan hanya dicatat secara sederhana. Dua dari tiga informan hanya mencatat pesanan yang masuk dan tidak membuat laporan keuangan secara lengkap. Padahal jika ditinjau ulang, perkembangan UMKM medorong pemerintah memberikan kemudahan pengajuan kredit dan akses permodalan.

Salah satu persyaratan yang diajukan guna memperoleh akses modal usahaadalah ketersediaan laporan keuangan sebagai pertimbangan prospek usaha. Laporan keuangan juga digunakan sebagai dasar pengukuran likuiditas guna meminimalkan resiko yang mungkin terjadi.

Dalam penyusunan laporan keuangan, tentu saja harus mengikuti kaidah umum yang berlaku. Untuk jenis usaha UMKM dapat mengacu pada informasi dan menarik isi kesimpulan. Bila sesuai dengan hasil wawancara dapat diterima dan di uji menggunakan teknik triangulasi maka hasil wawancara tersebut berkembang menjadi teori.

Standar Akuntansi Keuangan Entitas Mikro Kecil Menengah atau lebih dikenal dengan istilah SAK EMKM. Namun demikian, proses penyusunan laporan keuangan ini juga tidak terlepas dari sumber daya yang dimiliki entitas.

Kompetensi sumber daya manusia (SDM) menjadi hal yang dapat menentukan keberhasilan dari UMKM.. Kompetensi tersebut termasuk keahlian bagian keuangan dalam mengolah informasi menjadi pondasi dalam pengambilan keputusan ekonomik. Namun demikian, hasil dari observasi menunjukkan bahwa kompetensi SDM untuk UMKM batik di Kota Madiun masih sangat minim. Mereka sedikit mengesampingkan pencatatan karena kurangnya keterampilan manajerial utamanya dalam pengelolaan keuangan yang baik. Hal itu sebagaimana yang dinyatakan ke-2 informan dari dua UMKM batik yang menyatakan bahwa bagian keuangan dipegang oleh keluarga inti tanpa mempertimbangkan keahliannya dalam akuntansi.

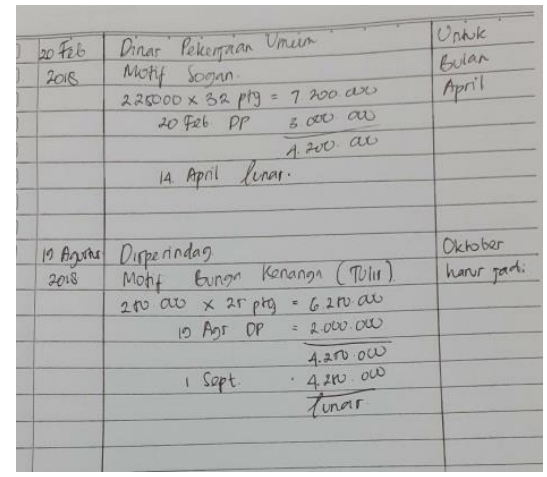

Gambar 1 Pencatatan Pesanan UMKM Batik Tulis Kenongo

Gambar 1 menunjukkan pencatatan keuangan pada UMKM Batik Tulis Kenongo hanya berisi mengenai rincian pesanan, uang muka, pelunasan pembayaran dan konfirmasi pengambilan. Hasil wawancara lanjutan menunjukkan bahwa catatan tersebut dibuat hanya untuk pengingat saja. Pembeli akan diberikan nota apabila telah melakukan pembayaran. Nota dibuat dalam dua rangkap. Rangkap pertama (nota asli) diberikan kepada pembeli sebagai bukti pembayaran pesanan, sedangkan rangkap kedua (berwarna merah muda) akan disimpan oleh penjual. Nota rangkap tersebut juga merupakan bentuk penendalian, dimana ketika pelanggan mengambil barang atau karyawan mengirimkan barangdapat diketahui kekurangan pembayarannya.

Gambar 2, 3, 4, dan 5 menunjukkan pencatatan keuangan yang terjadi pada UMKM Batik Arum Melati. Berdasarkan gambar tersebut diketahui bahwa pada UMKM Batik Arum Melati terdapat pembukuan untuk pesanan pelanggan, namun dalam buku tersebut hanya dilakukan secara 
tradisional yakni hanya memuat nama pemesan, pencatatan jumlah pesanan, estimasi biaya produksi yang dikeluarkan, jumlah uang muka yang dibayarkan oleh pembeli, dan jumlah uang muka serta tanggal pengambilan barang.

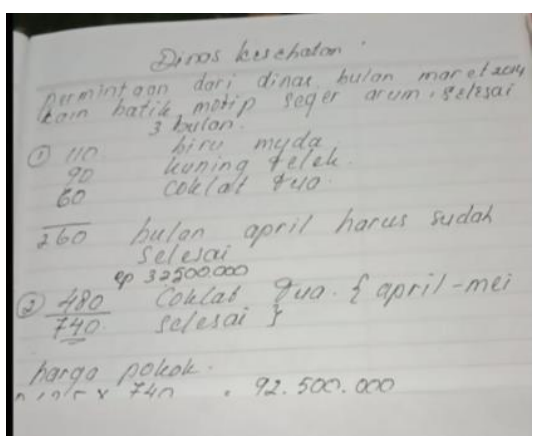

Gambar 2 Pencatatan Pesanan Batik Arum Melati kepada Dinas Tahun 2014

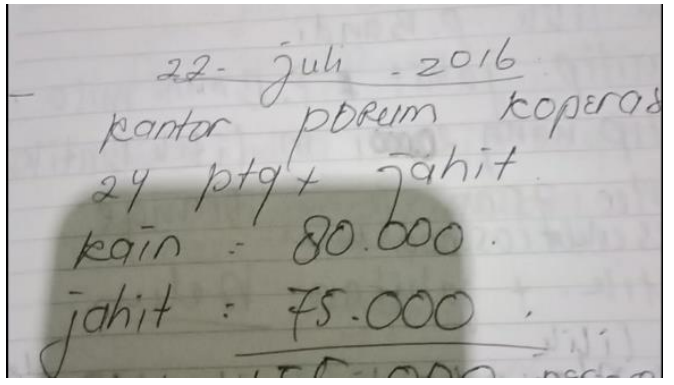

Gambar 3 Pencatatan Pesanan Batik Arum Melati kepada Kantor Koperasi Tahun 2016

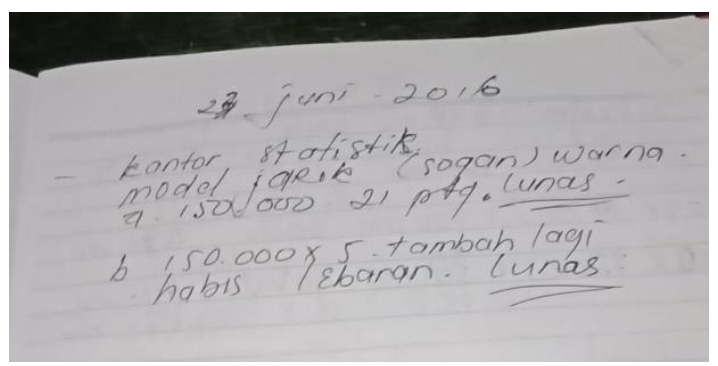

Gambar 4 Pencatatan Pesanan Batik Arum Melati kepada Kantor Statistik Tahun 2016

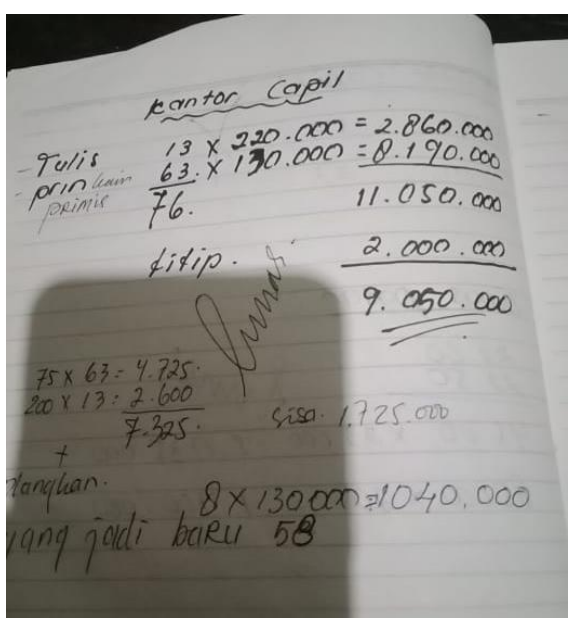

Gambar 5 Pencatatan Pesanan dan Pelunasan Batik Arum Melati 
Berdasarkan bukti tersebut dapat disimpulkan bahwa pencatatan masih dilakukan secara tradisional dan belum sesuai dengan prosedur pencatatan dalam akuntansi. Jika dikaji lebih mendalam catatan itu hanya memuat terkait dengan pendapatan yang diperoleh karena didalamnya hanya terdapat uang muka dan juga jumlah dari pelunasan atas pesanan batik. Jumlah pemakaian / biaya bahan baku masih diestimasikan, namun untuk biaya pengeluaran lain tidak dijelaskan secara gamblang bahkan tidak dilakukan pencatatan.

Hasil wawancara dengan informan pada UMKM Batik Arum Melati diketahui bahwa pencatatan yang dilakukan hanya bertujuan untuk pengingat mana saja pembeli yang melakukan pelunasan dan pembeli yang belum melakukan pelunasan. Sedangkan catatan pendukung lainnya tidak dibuat. Menurut informan, pencatatan rinci baru dilakukan ketika jumlah pesanan dalam kapasitas besar, sedangkan untuk pesanan dalam jumlah sedikit perhitungan dan pencatatannya hanya kira-kira saja.

Penelusuran mengenai kesiapan UMKM dalam menyusun laporan keuangan berbasis SAK ETAP dilanjutkan pada UMKM batik lainnya yaitu Galeri Batik Murni. Pada UMKM ini, pencatatan pembukuan dilakukan setiap hari ketika terjadi transkasi keuangan. Hal ini dibuktikan dengan adanya pembukuan yang dilakukan secara terperinci. Namun demikian, peneliti tidak diperkenankan untuk mendokumentasikan laporan pembukuan hariannya. Untuk itu penggalian informasi hanya berdasarkan wawancara serta neraca akhirnya.

Berdasarkan Gambar 6 dapat diketahui bahwa Galeri Batik Murni telah menyusun laporan keuangan. UMKM tersebut menyusun laporan keuangan dengan menggunakan aplikasi Microsoft Excel. Namun demikian dalam laporan neraca yang diberikan oleh informan, terdapat bebrapa aspek yang kurang sesuai dengan akuntansi berlaku umum.

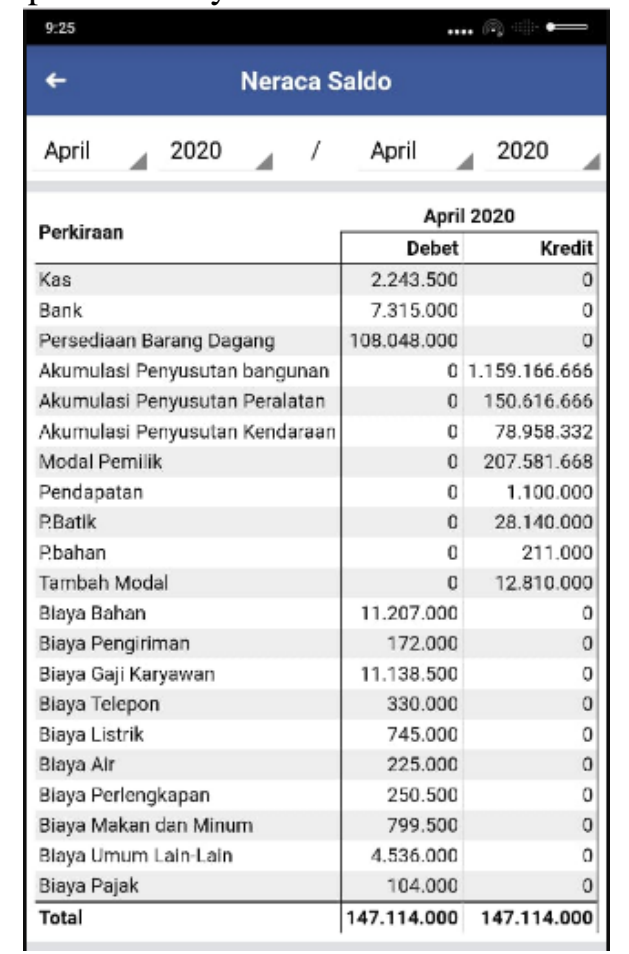

Gambar 6. Neraca Saldo Galeri Batik Murni

Sumber: Hasil data Galeri Batik Murni

Pada neraca saldo tersebut, jumlah debet dan kredit seimbang dengan nilai Rp.147.114.000, namun setelah peneliti hitung secara manual terdapat selisih Rp.291.470.332, karena total debet Rp.147.114.000,-, namun total kredit seharusnya Rp.438.584.332,-. Neraca saldo juga menunjukkan saldo akumulasi penyusutan yang cukup besar, sedangkan asset tetap yang susutkan tidak ada.

Hasil konfirmasi lanjutan kepada UMKM Galeri Batik Murni, informan menyatakan bahwa hasil tersebut sesuai dengan screenshot dari layar HP, sedangkan versi revisinya dilakukan 
menggunakan neraca lajur. Namun demikian peneliti tidak diijinkan mengakses data revisiannya. Berdasrkan data observasi, dokumentasi dan hasil wawancara, akhirnya peneliti dapat menyimpulkan bahwa pada penyusunan laporan keuangan UMKM Galeri Batik Murni belum menerapkan SAK EMKM.

Terdapat beberapa faktor internal yang menyebabkan seseorang tidak melakukan adanya pembukuan atau pencatatan laporan keuangan dengan baik salah satunya dari segi permodalan yang minim, sehingga para pelaku menganggap sepele hal tersebut. Padahal jika penyusunan sudah sesuai dengan SAK EMKM dapat menjadi pertimbangan bagi dinas untuk memberikan pinjaman modal yang lebih besar bagi UMKM. Hal lain yaitu terkait dengan Sumber Daya Manusia (SDM) terbatas.

Rofiaty (2012:66) mengungkapkan kendala lain dari UMKM adalah tidak adanya peran aktif dari UMKM di Jawa Timur dalam memasarkan produknya melalui internet, padahal internet dinilai sangat efisien dan efektif dalam penjualan produk. Hal itu juga didukung oleh Suyanto (2018:58) mengatakan hal ini disebabkan karena sehari-hari pelaku UMKM hanya mengandalkan teknologi yang sangat sederhana, kurang memiliki pendidikan, dan tidak adanya modal yang cukup untuk bersaing dengan sektor firma yang sudah dinilai mapan.

Hasil penelitian dan beberapa refernsi terdahulu tersebut menujukkan bahwa kebanyakan UMKM masih dalam skala keluarga. Mereka masih sangat membatasi jumlah karyawan dan penggunaan teknologi. Mereka berasumsi bahwa pembuatan laporan keuangan secara detail dan terperinci belum diperlukan. Untuk itu mereka lebih memilih mencatatnya secara manual atau dengan cara tradisional tanpa adanya pembukuan yang jelas.

Fokus utama UMKM batik di Kota Madiun adalah jumlah pemasaran dan produksi. Penambahan karyawan pun hanya difokuskan untuk membantu proses produksi. Dalam proses pengambilan keputusan ekonomik lebih ditekankan pada intuisi dan pengalaman pemilik selama menjalankan usaha UMKM batik.

Sebagaimana dijelaskan oleh Widjaja et al, (2018) bahwa faktor-faktor hambatan kemajuan UMKM adalah tingkat pendidikan pengetahuan dan keterampilan termasuk, keterampilan di bidang keuangan yang masih sangat minim sehingga hal ifulah vano akhirnva menurunkan standar kompetitif UMKM itu sendiri khususnya di bidang permodalan. Sejalan dengan itu Sulistyowati (2017) menyatakan bahwa harus ada sosialisasi terkait laporan keuangan secara berkelanjutan, karena pada realisasinya yang selama ini dilakukan hanya berupa seminar untuk menyampaikan gambaran teori dan belum secara praktiknya.

SAK EMKM (2018 bab 2 paragraf 2.1) menjelaskan mengenai laporan posisi keuangan, praktek keuangan serta laporan arus kas yang disusun pelaku UMKM akan dapat dijadikan sebagai keputusan ekonomi guna mewujudkan keperluan sebuah informasi. Dalam pemenuhan tujuan, laporan keuangan memperlihatkan apa yang sudah dilakukan oleh pihak manajemen atau sebagai tanggung jawab dari manajemen. Sehingga pelaku UMKM mampu menganalisis dan mengetahui informasi secara pasti terkait aset/kekayaan, liabilitas akan dinyatakan di dalam laporan posisi keuangan apabila pengeluaran ada manfaat ekonominya dan jumlahnya bisa dilakukan pengukuran yang dapat dipercaya.

Sedangkan pos lain yang dapat dijadikan bahan pertimbangan dalam pemerolehan laba adalah beban akan diakui dalam laporan laba rugi. Perkembangan usaha Batik UMKM di kota Madiun tidak selaras dengan pencatatan akuntansi, beberapa memiliki catatan pembukuan dengan cara sederhana serta tidak dibuat secara sistematis hal tersebut menyebabkan pelaku UMKM belum memiliki pemahaman terkait pentingnya akuntansi, padahal akuntansi dapat digunakan untuk mengetahui apakah usahanya berkembang atau tidak. Selain itu pelaku UMKM juga belum memiliki pencatatan keuangan yang sesuai atau belum menerapkan standar akuntansi keuangan. Persepsi kegunaan mulai dari persepsi kemudahan penggunaan dan kompetensi SDM menjadi hambatan utama kesiapan UMKM untuk mengimplementasikan SAK EMKM.

Kemampuan adalah ciri-ciri yang dimiliki seseorang sesuai dengan keterampilan pengetahuan dan juga keahlian dalam melakukan suatu pekerjaan. Perubahan standar pencatatan laporan keuangan berbasis SAK EMKM menuntut pelaku UMKM untuk bersiap melalui perekrutan SDM dengan kemampuan akuntansi yang memadai. Hal ini akan berdampak positif pada perkembangan UMKM karena pemilik mampu mengambil keputusan berdasarkan aspek-aspek riil yang tersaji dalam laporan keuangan. Bukan berdasarkan analisis intuitif dan pengalaman saja. Namun pada praktiknva ditemukan hahwa SDM di UMKM 
Batik Kota Madiun belum memahami proses pengukuran, pencatatan, penyajian, dan pengungkapan elemen-elemen dalam laporan keuangan yang berlaku umum atau berdasarkan SAK EMKM.

Wawasan dan pengetahuan terkait SAK EMKM tidak dimiliki oleh ketiga informan. Wawasan yang dimiliki hanya sebatas pencatatan pendapatan, utang dan piutang saja. Hal ini disebabkan oleh kurangnya sosialisasi dan pelatihan terkait penyusunan laporan keuangan berbasis SAK EMKM. Hasil wawancara secara mendalam, merujuk pada suatu simpulan bahwa menurut asumsi informan tidak ada standar yang mengatur pencatatan laporan keuangan. Selama ini mereka hanya mendapat sosialisasi tentang pengemasan produk dan startegi pemasaran saja.

Ketiga informan menyatakan bahwa pernah dilakukan sosialisasi terkait dasar pembukuan oleh beberapa lembaga mulai dari perbankan, lembaga keuangan non bank dan INKA. Namun kegiatan sosialisasi tersebut hanya mengupas dasar pencatatatan. Dinas terkait juga menegaskan memang belum ada sosialisasi tentang dasar pencatatan termasuk pembukuan berdasarkan SAK EMKM. Sementara ini mereka masih berfokus pada pendataan UMKM, pengembangan produk UMKM serta perluasan pemasaran produk kepada masyarakat luar Kota Madiun.

Perwakilan IAI komisariat Madiun menyatakan bahwa UMKM Kota Madiun memang belum menggunakan dasar pencatatan akuntansi yang benar. Untuk itu, penerapan SAK EMKM masih sangat sulit untuk dijalankan. Sejalan dengan hal itu Sholikin \& Setiawan, (2018) menyatakan bahwa ketidaksiapan dalam mengimplementasikan SAK EMKM karena kurangnya wawasan SDM pada UMKM. Kebanyakan mereka tidak mengerti ada regulasi khusus yang mengatur penyusunan laporan keuangan UMKM yaitu SAK EMKM. Pencatatan keuangan mereka biasanya masih menggunakan pembukuan dengan basis kas.

Kesiapan pelaku UMKM dalam penerapan SAK EMKM, merupakan suatu kemampuan seseorang untuk mengklasifikasikan, mengikhtisarkan pencatatan serta penyajian isi dari laporan keuangan sesuai dengan pedoman yang telah ditetapkan. Berdasarkan hasil observasi, wawancara dan dokumentasi dapat diketahui bahwa pelaku UMKM batik di Kota Madiun hampir seluruhnya belum mengetahui tentang SAK EMKM. Dengan demikian, mereka belum siap keuangannya sesuai standar akuntansi yang berlaku. Namun informan dalam penelitian ini menyatakan siap dan bersedia mengikuti ketentuan tersebut jika ada pengarahan dan sosialisasi mendalam terkait dengan standar akuntansi tersebut.

Sosialisasi dan pengadampingan secara intensif sangat diperlukan karena para pelaku usaha mayoritas belum mampu menerapkan prinsip business entity. Dalam menjalankan usahanya mereka belum mampu memisahkan antara kegiatan / transaksi keuangan yang berkaitan operasional usaha dengan pengeluaran yang bersifat pribadi. Hal ini tentu berdampak pada kredibilitas UMKM untuk mengakses modal eksternal yang sedikit diragukan.

Sejalan dengan hal itu, perwakilan dari IAI komisariat Madiun menyatakan bahwa pembuatan laporan keuangan berdasarkan SAK EMKM ini sangat diperlukan bagi pelaku UMKM. Laporan keuangan tersebut dapat digunakan untuk mengetahui posisi keuangan yang sebenarnya. Melalui laporan keuangan, pelaku UMKM dapat melakukan analisis mengenai bagaimana proses harta kekayaan yang dimiliki perusahaan dapat berkembang atau sebaliknya.

Hasil dari penelitian ini sejalan dengan Evi Puji Lestari (2018) yang menunjukkan bahwa pelaku UMKM pengrajin mebel di Desa Catak belum siap dalam pembuatan laporan keuangan berbasis SAK EMKM. Berdasarkan hasil wawancara yang dilakukan, informan I dan informan III yang menyatakan sudah siap apabila pemerintah mewajibkan penerapan SAK EMKM, namun mereka memerlukan pendampingan secara intensif. Sedangkan informan II menyatakan belum siap apabila harus membuat laporan keuangan sesuai dengan SAK EMKM karena keterbatasn SDM yang dimilikinya.

Berdasarkan data-data yang diperoleh serta analisis yang dilakukan, peneliti berasumsi bahwa UMKM batik di Kota Madiun belum siap menyusun laporan keuanganya berbasis SAK EMKM. Namun demikian, tidak menutup kemungkinan apabila ada sosialisasi khusus serta pendampingan secara intensif akan mengubah pandangan mereka mengenai urgensinya menyusun laporan keuangan. Judianto et al, (2018) menyatakan pentingnya ketersediaan laporan keuangan bagi UMKM, meskipun mereka merasa tidak membutuhkan informasi akuntansi dan berasumsi bahwa penyusuan laporan keuangan hanva membuang dana dan waktu karena 
keterbatasan sumber daya yang ada. Sejalan dengan itu, Nuvitasari et al (2019) menyatakan bahwa penyebab belum diimplementasikannya SAK EMKM pada praktik akuntansi pada UMKM adalah kurangnya wawasan pemilik sehingga tidak melakukan praktik akuntansi yang sesuai.

\section{SIMPULAN DAN SARAN}

Hasil penelitian menunjukkan bahwa pelaku UMKM batik Kota Madiun belum siap dalam penyusunan laporan keuangan berbasis SAK EMKM. Untuk itu, apabila pemerintah mewajibkan regualsi tersebut bagi pelaku UMKM, perlu diberikan pendampingan secara intensif. Hal ini dikarenakan pelaku UMKM batik di Kota Madiun masih melakukan penyusunan laporan keuangan secara secara tradisional sehingga belum sesuai dengan standar yang berlaku.

\section{DAFTAR PUSTAKA}

Arliani, L., Indrayani, L., Tripalupi, L. E., Studi, P., Ekonomi, P., \& Ganesha, U. P. (2019). Pengaruh Perilaku Pelaku Usaha dan Modal Usaha Terhadap Keberhasilan UMKM Di Desa Tukad Sumaga Kecamatan Gerokgak Kabupaten Buleleng. 11(2).

Evi Puji Lestari. (2018). Kesiapan UMKM Dalam Implementasi SAK EMKM Pengrajin Mebel DesaCatak Gayam, Mojowarno. 2(1), 24-33.

Huda, A. F. (2017). Apa Itu Ekonomi Kreatif. Istana Media.

Judianto, R., Ismunawan, \& Rahman, A. N. (2018). Implementasi Penyusunan Laporan Keuangan UMKM Berdasarkan Standar Akuntansi Keuangan Entitas Mikro Kecil dan Menengah (SAK-EMKM) Pada UKM Davin Decor Surakarta. 4(02), 79-98.

Kasus, S., Buleleng, K., Gede, L., Dewi, K., Gede, L., \& Mekar, J. (2019). Analisis Kesiapan dan Pengetahuan dalam Penyusunan Laporan Keuangan Berbasis Standar Akuntansi Keuangan EMKM. Jurnal Ilmiah Akuntansi, 4(2), 141-160.

Nuvitasari, A., Y, N. C., \& Martiana, N. (2019). Implementasi SAK EMKM Sebagai Dasar Penyusunan Laporan Keuangan Usaha Mikro Kecil dan Menengah ( UMKM ). 3(3), 341-347.

Rafiqa, F. (2018). Analisis Tingkat Pemahaman dan Tingkat Kesiapan UMKM Dalam Implementasi SAK EMKM Dalam Pelaporan Keuangan Di Kota Padang.

Rofiaty. (2012). INOVASI DAN KINERJA: Knowledge Sharing Behaviour Pada UKM (Ismiatun (Ed.)). Universitas Brawijaya Press (UB Press).

Salmiah, N., Indarti, \& Inova Fitri Siregar. (2015). Analisis Penerapan Akuntansi dan Kesesuaiannya dengan Standar Akuntansi Keuangan Entitas Tanpa Akuntabilitas Publik (Pada UMKM di Kecamatan Sukajadi Binaan DisKop \& UMKM Kota Pekanbaru). Akuntansi, 3(2), 212-226.

Savitri, R. V. (2018). Pencatatan Akuntansi pada Usaha Mikro Kecil dan Menengah ( studi pada UMKM Mr . Pelangi Semarang) : 5(2), 117-125.
Keterbatasan penelitian ini adalah pembatasan akses laporan keuangan secara komprehensif di UMKM Batik Kota Madiun, sehingga analisis dan sintesis hanya berdasarkan dokumen dan informasi yang tersedia dengan menggunakan metode deskriptif. Bagi peneliti selanjutnya, dapat menggunakan paradigma kualitatif lainnya untuk menghasilkan pemahaman yang lebih mendalam terhadap objek yang diteliti.

Implementasi SAK ETAP: Studi Kasus Pada Pengusaha UMKM Garmen Di Pusat Grosir Surabaya. 79-83.

Sholikin, A., \& Setiawan, A. (2018). Kesiapan Umkm Terhadap Implementasi SAK EMKM (Studi UMKM Di Kabupaten Blora). Journal of Islamic Finance and Accounting, $1(2), \quad 35$. https://doi.org/10.22515/jifa.v1i2.1441

Sulisti, T. (2019). Analisis Tingkat Pemahaman dan Kesiapan Pelaku Usaha Mikro Kecil Menengah (UMKM) dalam Implementasi Standar Akuntansi Keuangan Entitas Mikro, Kecil, dan Menengah (SAK EMKM). FLEPS 2019 - IEEE International Conference on Flexible and Printable Sensors and Systems, Proceedings, 6(1), 1-46. https://doi.org/10.1016/j.surfcoat.2019.125084

Sulistyowati, Y. (2017). Pencatatan Pelaporan Keuangan UMKM (Study Kasus di Kota Malang). 5(2), 49-55.

Suyanto, B. (2018). Kemiskinan, Konflik, dan Ekses Pembangunan (Pertama). Suluh Media.

Undang Undang No. 20. (2008).

Widjaja, Y. R., Alamsyah, D. P., Rohaeni, H., \& Sukajie, B. (2018). Peranan Kompetensi SDM UMKM Dalam Meningkatkan Kinerja UMKM Desa Cilayung Kecamatan Jatinangor, Sumedang. 1(3), 465-476. 